\title{
Effect of different sources of alumina on the microstructure and mechanical properties of the triaxial porcelain
}

\section{(Efeito de diferentes fontes de alumina na microestrutura $e$ propriedades mecânicas de porcelanas triaxiais)}

\author{
G. Gralik, A. L. Chinelatto ${ }^{2}$, A. S. A. Chinelatto \\ Department of Materials Engineering, State University of Ponta Grossa, Av. Carlos Cavalcanti 4748, \\ Ponta Grossa, PR, Brazil 84030-900 \\ 'guilherme_gralik@yahoo.com.br, ${ }^{2}$ adilson@uepg.br, ${ }^{3}$ adriana@uepg.br
}

\begin{abstract}
Porcelains composed of kaolin-quartz-feldspar are called triaxial porcelains. The use of alumina as a substitute for quartz in porcelains has been developed for some time. The results show a significant improvement in their mechanical properties, but alumina has a high cost. The possibility of using alternative materials as a source of alumina with lower cost was investigated. In this work, alternative raw materials were used as a source of alumina: refractory bauxite, primary aluminum hydroxide, reprecipitated aluminum hydroxide. Compositions with commercial alumina and quartz were also formulated to better understand the effects of adding these alternative materials. The raw materials were milled, dried, and characterized by analysis of the particle size distribution, X-ray diffraction, and X-ray fluorescence. The compositions were formulated by replacing the different sources of alumina in the formulation of porcelain. The compositions studied were shaped by pressing and sintered at different temperatures $\left(1150-1400{ }^{\circ} \mathrm{C}\right)$. The results showed that the use of bauxite and aluminum hydroxide as an alternative source of $\mathrm{Al}_{2} \mathrm{O}_{3}$ is viable. The impurities contained in refractory bauxite contributed to the lower values of flexural strength found in compositions having refractory bauxite as a source of alumina. The compositions with reprecipitated aluminum hydroxide showed a high mechanical resistance at low sintering temperatures, while compositions with aluminum hydroxide obtained by the Bayer process achieved good results of mechanical strength in a wide temperature range.
\end{abstract}

Keywords: quartz, aluminium hydroxide, porcelain, bauxite.

Resumo

Porcelanas compostas de caulim-quartzo-feldspato são denominadas porcelanas triaxiais. $O$ uso de alumina como substituito para o quartzo em porcelanas tem sido desenvolvido há algum tempo. Os resultados mostram uma significativa melhoria nas priopriedades mecânicas, mas a alumina apresenta alto custo. Foi investigada a possibilidade de utilizar materiais alternativos como fonte de alumina a custos menores. Neste artigo, as seguintes matérias primas alternativas foram utilizadas como fonte de alumina: bauxita refratária, hidróxido de alumínio primário, e hidróxido de alumínio reprecipitado. Composições com quartzo e alumina comerciais foram também formuladas para melhor entendimento dos efeitos de adição desses materiais. As matérias primas foram moídas, secas, e caracterizadas por análise de distribuição de tamanho de partículas, difração de raios $X$ e fluorescência de raios $X$. As composições foram formuladas substituindo as diferentes fontes de alumina na formulação da porcelana. As composições foram conformadas por compactação e sinterizadas a diferentes temperaturas (1150-1400 $\left.{ }^{\circ} \mathrm{C}\right)$. Os resultados mostraram que é viável o uso de bauxita e de hidróxido de alumínio como fonte alternativa de $\mathrm{Al}_{2} \mathrm{O}_{3}$. As impurezas na bauxita refratária contribuíram para diminuir os valores de resistência à flexão encontrados em composições com bauxita refratária como fonte de alumina. As composições com hidróxido de alumina reprecipitado mostraram alta resistência mecânica a baixas temperaturas de sinterização, enquanto que composições com hidróxido de alumínio obtidos pelo processo Bayer alcançaram bons resultados de resistência mecânica em ampla faixa de temperaturas.

Palavras-chave: quartzo, hidróxido de alumínio, porcelana, bauxita.

\section{INTRODUCTION}

Porcelains are used in manufacturing a wide variety of products due to the low cost of the natural raw materials $[1,2]$. A wide range of triaxial porcelain compositions are found in the literature [3-10], containing clay, feldspar, and quartz, and/or alumina [2,11]. The mechanical properties of porcelains are largely dependent on their microstructure. The microstructure is developed during the ceramic processing and the main factors that can affect the mechanical strength of porcelain are: coefficient of thermal expansion, mechanical properties of the present phases, homogeneous distribution of particles in the glassy phase, particle size of the crystalline phases, volume fraction of the present phases, and the phase transformations [12].

During sintering porcelain, several chemical reactions 
Table I - Compositions analysed.

[Tabela I - Composições analisadas.]

\begin{tabular}{ccccccccc}
\hline Composition & $\begin{array}{c}\text { Quartz } \\
(\%)\end{array}$ & $\begin{array}{c}\text { Refractory } \\
\text { bauxite }(\%)\end{array}$ & $\begin{array}{c}\text { Aluminum } \\
\text { hydroxide* }^{*}(\%)\end{array}$ & $\begin{array}{c}\text { Aluminum } \\
\text { hydroxide }\end{array}$ (\%) & $\begin{array}{c}\text { Alumina } \\
(\%)\end{array}$ & $\begin{array}{c}\text { Feldspar } \\
(\%)\end{array}$ & $\begin{array}{c}\text { Kaolin } \\
(\%)\end{array}$ & $\begin{array}{c}\text { Clay } \\
(\%)\end{array}$ \\
\hline Q & 30 & - & - & - & - & 35 & 25 & 10 \\
B & - & 30 & - & - & - & 35 & 25 & 10 \\
RH & - & - & 30 & - & - & 35 & 25 & 10 \\
BH & - & - & - & 30 & - & 35 & 25 & 10 \\
A & - & - & - & - & 30 & 35 & 25 & 10 \\
\hline
\end{tabular}

* Reprecipitated aluminium hydroxide; ** Bayer aluminium hydroxide

occur and are influenced by temperature, time, furnace atmosphere, and especially the composition of the porcelain. The main reactions that occur during the sintering process of triaxial porcelains are the formation of mullite (primary and secondary), the phase change of quartz, and the liquid phase formation [13-17]. The mullite formed from the plastic components is referred to as primary mullite, while that formed from the feldspar is called secondary or acicular mullite $[18,19]$. The local composition of liquid phase present during the sintering process determines the type and amount of mullite as well as the rate of dissolution of quartz (and/ or alumina) $[17,19]$. The composition is an important factor during sintering because, along with the temperature [20, 21], it determines the final microstructure of the porcelain. Thus, a small change in the composition of both raw materials is enough to change the characteristics of the liquid phase and consequently the properties of porcelain [22-26].

The use of alumina as a substitute for quartz in the formulations of porcelain has been in development for some time, with promising results in respect to mechanical characteristics, but not such good in relation to the linear shrinkage [27] and the high cost of alumina. Alumina crystals are a decisive factor to increase the strength in porcelain containing alumina due of its high Young's modulus and his direct correlation between strength, The embedded alumina crystals should have a particle size ranging from small to medium with an average particle diameter of $\sim 10 \mu \mathrm{m}$, and they should be distributed in the microstructure as uniformly as possible [20].

Another important aspect that is characteristic of the microstructure of porcelain is the presence of cracks generated by the effects of stresses caused by the difference between the coefficients of thermal expansion of quartz $\left(23 \times 10^{-6} \mathrm{C}^{-1}\right)$ and the glassy phase $\left(3 \times 10^{-6} \mathrm{C}^{-1)}\right.$ in the temperature range between 20 and $700{ }^{\circ} \mathrm{C}$. This crack can be avoided with the substitution of the alumina, its thermal expansion coefficient being $8 \times 10^{-6} \mathrm{C}^{-1}$ in the same temperature range [11].

Some economically viable alternative sources of alumina are refractory bauxite, aluminium hydroxide obtained by the Bayer process, and reprecipitated aluminium hydroxide. Brazil has the third largest reserves of bauxite in the world ( 2.5 billion tons), found in the Amazon region to the north and the south in the region of Poços de Caldas, MG, and Cataguases, MG [28]. Bauxite is the main mineral source of aluminum and is an aluminum hydroxide, preferably a gibbsite (in the case of Brazil) and, more rarely, boehmite and/or diaspore. Minor constituents comprise mainly clay minerals, particularly kaolinite, oxides and iron hydroxides of haematite $\left(\mathrm{Fe}_{2} \mathrm{O}_{3}\right)$ and goethite $(\mathrm{FeO}(\mathrm{OH}))$, titanium oxide $\left(\mathrm{TiO}_{2}\right)$, and silica in the form of quartz $\left(\mathrm{SiO}_{2}\right)[29,30]$. In the production process in Brazil, raw bauxite is calcined in a rotary furnace at temperatures above $1650{ }^{\circ} \mathrm{C}$, the concentrations of $\mathrm{TiO}_{2}$ and $\mathrm{AlTiO}_{5}$ obtained by the products are low, and high amounts of silica with low amounts of alkali contribute to a greater amount of mullite [31]. Synthetic aluminum hydroxide is obtained industrially by dissolution in caustic soda and recrystallization of the gibbsite contained in the bauxite by the Bayer process. Its particles are made up of agglomerates of primary crystals which are formed during the recrystallization step [32]. In the Bayer process, bauxite is digested in caustic soda under elevated temperature and pressure to solubilize the precipitated aluminum hydroxide and insoluble complexes with silica. Calcination is the final step for obtaining alumina. Its main objective is the conversion of the hydrate into a mixture of crystalline allotropic forms of $\mathrm{Al}_{2} \mathrm{O}_{3}$ or a specific phase [33].

Alumina occurs in nature as the mineral known as corundum, the crystal structure with the same name as the mineral [34]. The alumina formed from crystalline aluminum hydroxide at temperatures below $1000{ }^{\circ} \mathrm{C}$ is called transition alumina. The $\alpha$-alumina is not a transition alumina; it is a thermodynamically stable structure formed by heating from $1000{ }^{\circ} \mathrm{C}[35,36]$. Because it is a synthetic material, $\alpha$-alumina has high chemical stability and particle size, particularly when compared to other natural sources of aluminum oxide [37]. $\alpha$-alumina is used in some types of porcelain, partially or totally replacing quartz with the aim of improving the mechanical strength [20,27].

The purpose of this study was to evaluate the effect of different sources of alumina on the microstructure and properties of the porcelain. Therefore, quartz was replaced in the composition of porcelain by different raw materials sources of alumina, such as aluminum hydroxide, calcined alumina, and bauxite.

\section{MATERIALS AND METHODS}

The following raw materials were used: Gnata clay, Hori 
kaolin, quartz (Marc Ind. Com. Ltda.), potassium feldspar (Marc Ind. Com. Ltda.), refractory bauxite (Possehl of Brazil Imp. Exp. Trade), reprecipitated aluminium hydroxide Hidral 710 (Almatis), aluminium hydroxide $\mathrm{C} 30$ obtained by the Bayer process (Raw Material Proceramica), and alumina A1000 SG from Alcoa Inc. (Almatis). Aluminium hydroxide $\mathrm{C} 30$ is obtained from the Bayer process and is manufactured by Alcoa in Brazil in Pocos de Caldas, MG, and aluminium hydroxide Hidral 710 is imported from Germany by the company Almatis. They differ in their methods of production: the national aluminum hydroxide product is a result of crystallization of the aluminate liquor obtained after dissolution in caustic soda, while aluminium hydroxide Hidral 710 is obtained by successive recrystallization of the aluminate liquor.

The refractory bauxite was ground for $24 \mathrm{~h}$, while quartz, feldspar, clay, and kaolin were milled for $6 \mathrm{~h}$ in a ball mill with a wet ball using a ball:material ratio $2: 1$. The difference in the time of grinding of refractory bauxite was due to its high hardness and particle size. After milling, the raw materials were dried at $100{ }^{\circ} \mathrm{C}$ for $24 \mathrm{~h}$ and then sieved through tyler 80 mesh. The aluminum hydroxides and alumina were not ground.

The raw materials were characterized by particle size distribution, X-ray diffraction (XRD), and X-ray fluorescence (XRF). To determine the particle size distribution, a Cilas 920 granulometer was used. The mineralogical composition of the raw materials was determined by XRD on Shimadzu XDR 6000 equipment under diffraction conditions of $2 \theta$ ranging from $5^{\circ}$ to $90^{\circ}$ and a scan rate of $2^{\circ} / \mathrm{min}$, and the patterns were identified on the basis of Match Phase Identification from the Powder Diffraction version 1.11. The chemical analysis of the raw materials was performed by X-ray fluorescence spectroscopy using Shimadzu EDX-700 equipment.

Four compositions in which quartz was replaced with raw materials as sources of alumina and the contents of clay, feldspar, and kaolin were held constant. The base composition of the porcelain was $10 \mathrm{wt} . \%$ clay, $25 \mathrm{wt} . \%$ kaolin, $35 \mathrm{wt} . \%$ feldspar, and $30 \mathrm{wt} . \%$ quartz, denoted Q. The formulations of the ceramic bodies studied are presented in Table I.

The compositions were prepared from a mixture of raw materials by ball milling for $6 \mathrm{~h}$ and adding $1 \mathrm{wt} . \%$ dispersant (sodium silicate). After mixing, the compositions were dried at $100{ }^{\circ} \mathrm{C}$ for $24 \mathrm{~h}$, deagglomerated in a mortar, and sieved through tyler 80 mesh. To aid the compaction process, $6 \mathrm{wt} . \%$ water was added. The compositions were processed by uniaxial pressing in a metal mould $60 \mathrm{~mm}$ long and $13 \mathrm{~mm}$ wide with a compaction pressure of $200 \mathrm{MPa}$. The specimens were sintered between 1150 and $1400{ }^{\circ} \mathrm{C}$ in an electric furnace with a heating ramp of $300^{\circ} \mathrm{C} / \mathrm{h}$ up to $1000^{\circ} \mathrm{C}$ and $200^{\circ} \mathrm{C} / \mathrm{h}$ to the final temperature, which was maintained for 2 h. After sintering, the samples were characterized by various measurements: apparent porosity, water absorption, bulk density by the Archimedes method, and flexural strength at three points, determined on a Shimadzu Autograph AGS 10 $\mathrm{KN}$ universal testing machine. The phases formed during the sintering process were determined by XRD using the same equipment and conditions as for the analysis of raw materials. For microstructural study, sintered samples were polished with $0.3 \mu \mathrm{m}$ alumina after grinding. The polished surface of each sample was etched for $15 \mathrm{~s}$ in $5 \%$ HF solution at room temperature and washed in water, after which gold sputter coating was carried out (Shimadzu IC 50 Ion Coater). Scanning electron microscopy (SEM, Shimadzu SS 550) was used to obtain secondary and backscattering electron images.

\section{RESULTS AND DISCUSSION}

Table II shows the results of chemical analysis of the raw materials. Iron oxide comprises $1.22 \%$ of the bauxite.

Table II - Major chemical elements present in the raw materials.

[Tabela II - Principais elementos químicos nas matérias-primas.]

\begin{tabular}{|c|c|c|c|c|c|c|c|c|}
\hline $\begin{array}{l}\text { Chemical } \\
\text { element }\end{array}$ & $\begin{array}{l}\text { Refractory } \\
\text { Bauxite }\end{array}$ & $\begin{array}{l}\text { Aluminum } \\
\text { hydroxide * }\end{array}$ & $\begin{array}{l}\text { Aluminum } \\
\text { hydroxide** }\end{array}$ & Alumina & Quartz & Feldspar & Clay & Kaolin \\
\hline $\mathrm{Al}_{2} \mathrm{O}_{3}$ & 82.00 & 95.93 & 95.86 & 99.80 & 11.49 & 22.90 & 25.90 & 49.62 \\
\hline $\mathrm{SiO}_{2}$ & 10.86 & 2.17 & 1.93 & 0.09 & 85.19 & 74.91 & 66.02 & 45.42 \\
\hline $\mathrm{TiO}_{2}$ & 3.44 & 0.07 & - & - & 0.27 & - & 3.41 & 0.17 \\
\hline $\mathrm{Fe}_{2} \mathrm{O}_{3}$ & 1.22 & 0.06 & 0.09 & 0.09 & 0.27 & 0.99 & 3.12 & 1.35 \\
\hline $\mathrm{SO}_{3}$ & 0.87 & 1.72 & 1.86 & - & 1.89 & - & - & 1.11 \\
\hline $\begin{array}{c}\text { Chemical } \\
\text { element }\end{array}$ & $\begin{array}{c}\text { Refractory } \\
\text { Bauxite }\end{array}$ & $\begin{array}{c}\text { Aluminum } \\
\text { hydroxide * }\end{array}$ & $\begin{array}{c}\text { Aluminum } \\
\text { hydroxide** }\end{array}$ & Alumina & Quartz & Feldspar & Clay & Kaolin \\
\hline $\mathrm{K}_{2} \mathrm{O}$ & 0.68 & - & - & - & 0.84 & 0.96 & 1.11 & 2.33 \\
\hline $\mathrm{CaO}$ & 0.54 & - & 0.18 & 0.02 & - & - & 0.31 & - \\
\hline $\mathrm{SrO}$ & - & - & - & - & - & 0.18 & - & - \\
\hline $\mathrm{ZrO}_{2}$ & 0.19 & - & - & - & 0.05 & 0.06 & 0.13 & - \\
\hline $\mathrm{Cr}_{2} \mathrm{O}_{3}$ & 0.20 & 0.05 & 0.08 & - & - & - & - & - \\
\hline
\end{tabular}

* Reprecipitated aluminum hydroxide; ** Bayer aluminum hydroxide. 
Potassium and calcium oxides make up about $1.17 \%$ and can act as a flux, lowering the sintering temperature and contributing to the increase of the glass phase. The reprecipitated aluminum hydroxide contains $2.17 \%$ silicon, and the amount of titanium oxides and iron totals $0.13 \%$, a higher value compared to Bayer aluminum hydroxide, which has only $0.08 \%$ iron oxide and no titanium oxide. The silica contents are also lower in material obtained by the Bayer process, comprising $1.93 \%$ of the hydroxide. Alumina is the purest raw material, with $99.80 \% \mathrm{Al}_{2} \mathrm{O}_{3}$. Quartz has $1.38 \%$ iron, titanium, and potassium all at oxide form, and a higher amount of silica, $85.19 \%$ and a considerable amount of alumina, $11.49 \%$. This alumina content can be associated with the presence of clay minerals in the quartz. The clay used is rich in titanium oxides and iron, potassium, calcium which can lower the temperature of formation of the liquid phase. The kaolin has oxides of titanium, iron, and 3.85\% potassium in its chemical composition.

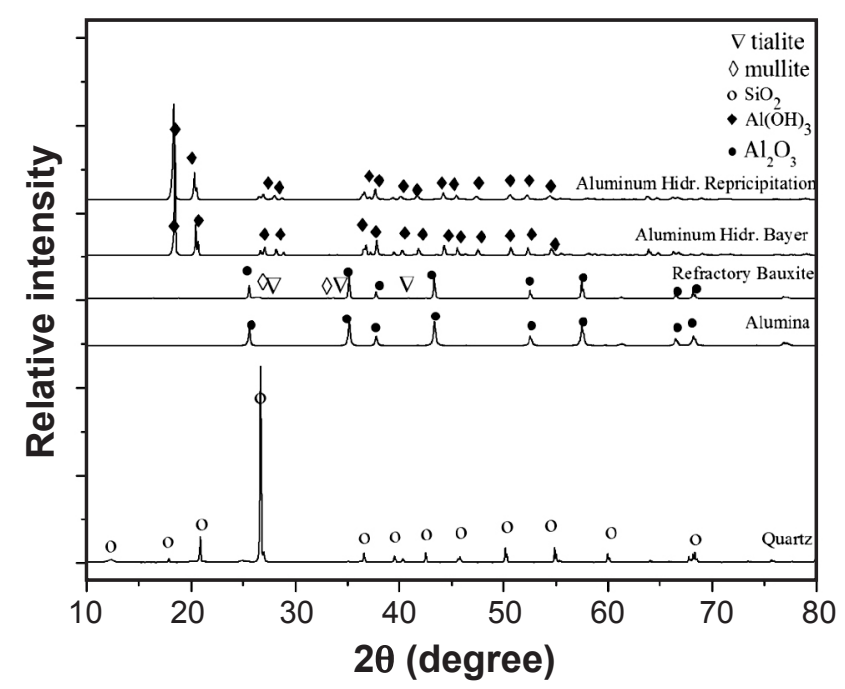

Figure 1: X-ray diffraction patterns of the raw materials. [Figura 1: Diffratogramas de raios X das matérias-primas.]

Fig. 1 shows XRD results of the raw materials used as source of alumina. Alumina presents only peaks of $\alpha$-alumina. Bayer aluminum hydroxide and reprecipitated aluminum hydroxide have the same diffraction pattern, with peaks of aluminum hydroxide $\left(\mathrm{Al}(\mathrm{OH})_{3}\right)$, which is referred to as the gibbsite phase. In bauxite, peaks relating to $\alpha$-alumina, mullite, and tialite $\left(\mathrm{Al}_{2} \mathrm{TiO}_{5}\right)$ are present, indicating that it has been calcined at high temperatures.

The analysis of the particle size distribution of the raw materials used as sources of alumina and quartz is shown in Fig. 2. There is a large variation in average size and size distribution. The aluminum hydroxide obtained by the Bayer process is the one with the largest average particle size, $\mathrm{D}_{50 \%}$, of $84.5 \mu \mathrm{m}$. This result is due to the fact that in the process of obtaining aluminum hydroxide, it is obtained in the form of agglomerates of primary crystals. The other raw materials used in the substitution have average sizes lower than that of quartz, and aluminum hydroxide and reprecipitated alumina

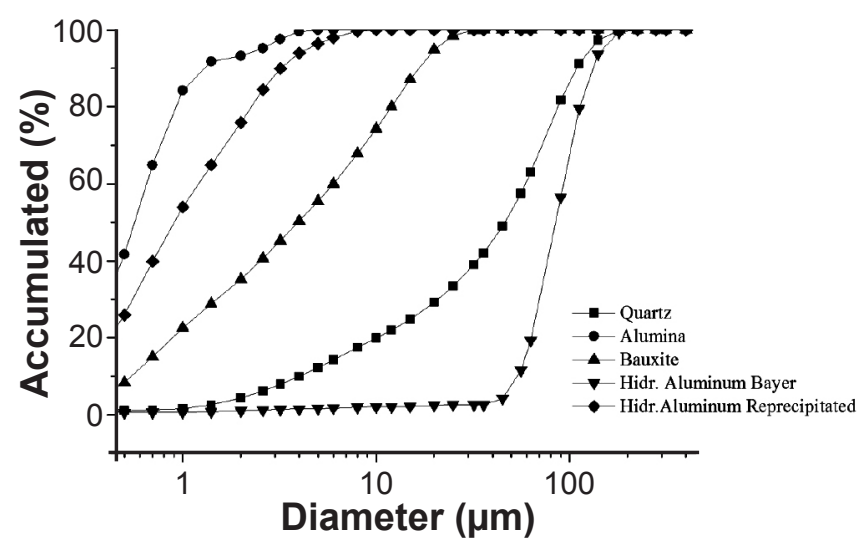

Figure 2: Curves of particle size distribution of the raw materials: quartz, bauxite, reprecipitated aluminum hydroxide, Bayer aluminium hydroxide, and alumina.

[Figura 2: Curvas de distribuição de tamanho de partícula das matérias-primas: quartzo, bauxita, hidróxido de aluminio reprecipitado, hidróxido de alumínio Bayer, e alumina.]

have smaller particle sizes, less than $1 \mu \mathrm{m}$.

The bulk density and apparent porosity of the compositions sintered between 1150 and $1400{ }^{\circ} \mathrm{C}$ are shown in Figs. 3 and 4, respectively. The lower densities and higher apparent porosities are found at $1150^{\circ} \mathrm{C}$, where the samples have not undergone significant changes due to sintering. With the increased sintering temperature, the porosity decreases for all compositions, becoming close to zero. This characteristic is due to the sequence of reactions that occur in the sintering of the specimens, such as the formation of liquid phase from feldspar, kaolin decomposition, and lower viscosity of the liquid phase [38,39].

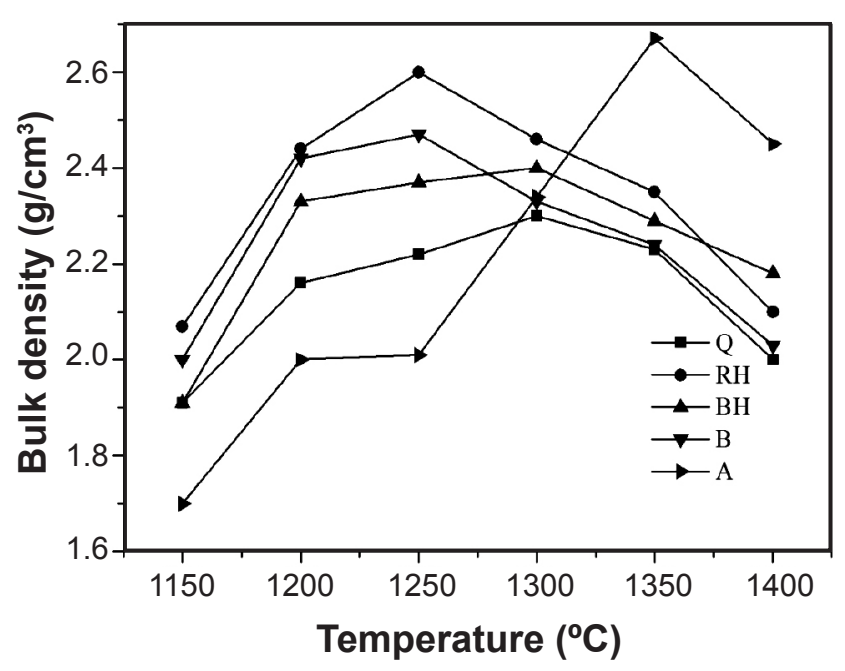

Figure 3: Values of bulk density as a function of sintering temperature for compositions Q (quartz), RH (reprecipitated aluminium hydroxide), BH (Bayer aluminium hydroxide), B (refractory bauxite) and A (alumina).

[Figura 3: Valores de densidade aparente em função da temperatura de sinterização das composições $Q$ (quartzo), $R H$ (hidróxido de alumínio reprecipitado), $\mathrm{BH}$ (hidróxido de alumínio Bayer), B (bauxita refratária) e A (alumina).] 
For all compositions, the density increases with the sintering temperature to a maximum value and above this temperature it decreases. The density increase is associated with the formation of liquid phase which fills opened pores, causing densification of the compact. As in all cases the amount of feldspar is kept constant, and the difference in temperature at which the maximum densities are achieved is due to the impurities of other constituents that compose the formulations, which influence the composition of the liquid phase and its viscosity. Except for alumina, all materials used as a source of alumina contain a certain amount of impurities; the refractory bauxite, for example, has only $82 \%$ alumina, while reprecipitated aluminium hydroxide has $95.86 \%$.

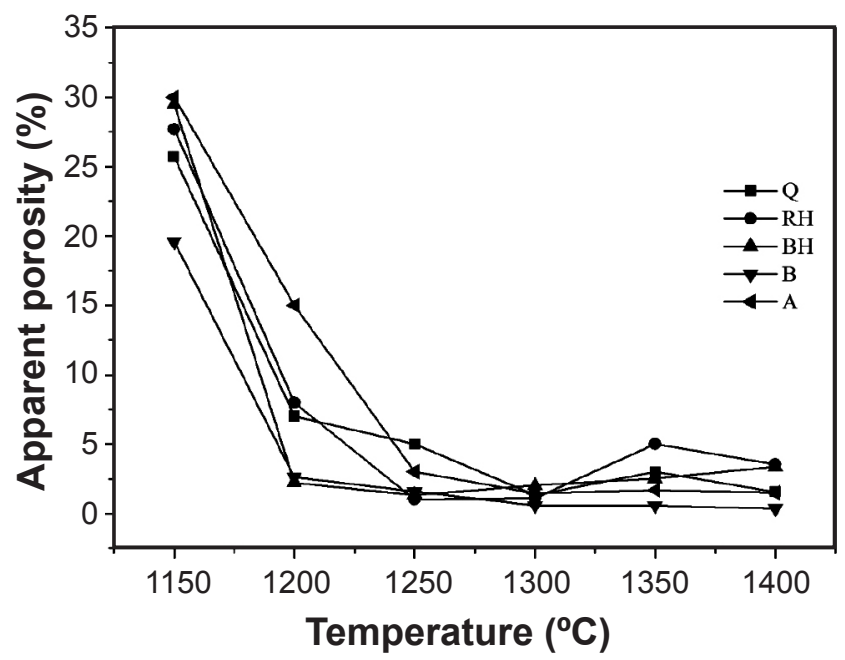

Figure 4: Apparent porosity as a function of sintering temperature for compositions Q (quartz), RH (reprecipitated aluminium hydroxide), BH (Bayer aluminium hydroxide), B (refractory bauxite) and A (alumina).

[Figura 4: Valores de porosidade aparente em função da temperatura de sinterização para as composições $Q$ (quartzo), $R H$ (hidróxido de alumínio reprecipitado), $\mathrm{BH}$ (hidróxido de alumínio Bayer), B (bauxita refratária) e A (alumina).]

Bauxite caused a lowering of the maximum density at the temperature of $1300{ }^{\circ} \mathrm{C}$ for the composition containing quartz and at the temperature of about $1250{ }^{\circ} \mathrm{C}$ for the bauxite composition, probably due to the change of the flux phase. As noted in Table I, bauxite has a relatively large amount of impurities such as $\mathrm{Fe}_{2} \mathrm{O}_{3}, \mathrm{~K}_{2} \mathrm{O}$, and $\mathrm{CaO}$, which should have been incorporated into the glassy phase and decreased the temperature of formation of this phase. Bauxite also reduced the firing range of the composition because, as can be seen in Fig. 2, the density reached a maximum at $1250{ }^{\circ} \mathrm{C}$, and then decreased sharply when the temperature increased to $1300{ }^{\circ} \mathrm{C}$. The same behavior as exhibited by the bauxite can be observed for the composition with reprecipitated aluminum hydroxide. The temperature of maximum density and firing range diminished when the quartz was replaced by reprecipitated aluminum hydroxide. As for the composition with Bayer aluminum hydroxide, the density reached a maximum at $1200{ }^{\circ} \mathrm{C}$ and remained almost unchanged until
$1300{ }^{\circ} \mathrm{C}$ was reached, after which the density decreased. For the composition containing alumina, the maximum density was achieved at higher temperatures of around $1350{ }^{\circ} \mathrm{C}$. The effect of decreasing density at high temperatures is associated with the formation of bubbles from the glass phase, which give rise to closed pores. With increasing temperature, the expansion of the gases ("bloating") occurs in the closed pores, which leads to the formation of larger pores than at the lower temperature. This causes the volume of the closed porosity to increase, but the one of open porosity decreases as the amount of glass phase tends to increase with increasing temperature, occupying the open pores [38]. The origin of trapped gases in the glassy phase can be associated with the loss of hydroxyl $(\mathrm{OH})$ of kaolinite crystals, and the release of oxygen due to the decomposition of ferric oxide $\left(\mathrm{Fe}_{2} \mathrm{O}_{3}\right.$ to $\left.\mathrm{Fe}_{3} \mathrm{O}_{4}\right)$ [38]. With the formation of closed porosity, the volume of the body increases while the mass remains constant, and then the density of the specimen decrease with increasing temperature. As apparent porosity measures only the open pores, there is a reduction in porosity with increasing sintering temperature.

Fig. 5 shows the XRD results of all the studied compositions sintered at different temperatures. In all these compositions, the crystalline phases of alumina, mullite, and quartz were identified. From the XRD patterns of the composition with quartz (Fig. 5a) at $1150{ }^{\circ} \mathrm{C}$, it was observed that the peaks associated with the quartz were more intense, and when the temperature increased, the intensity of these peaks decreased, due to their partial dissolution in the glassy phase. It is also noted that the peaks relating to the mullite phase become more apparent as the sintering temperature is increased. In Fig. 5b, in which there is replacement of quartz by bauxite, diffraction peaks of alumina, mullite, and quartz are present. The peaks of quartz are present due to the raw material. Also, at $1150^{\circ} \mathrm{C}$ the peaks of albite can be observed, further indicating that there was no complete fusion of feldspar. With the increase in the temperature, the intensity of quartz peaks decreased, the mullite peaks increased, and the alumina peaks remained almost constant. For compositions with reprecipitated aluminium hydroxide (Fig 5c), the alumina peaks practically disappeared at temperatures above $1350^{\circ} \mathrm{C}$, suggesting that there was dissolution of alumina in the glassy phase. Several studies $[22,23]$ show that the dissolution of alumina in the glassy phase is too slow, but in this case it was clearly observed that it was almost completely dissolved at the higher sintering temperatures. This high dissolution may be associated with the nature of alumina particles which were produced by transformation of aluminium hydroxide into alumina during sintering. In compositions with Bayer aluminium hydroxide and calcined alumina (Figs. 5d and 5e), the intensity of the alumina diffraction peaks remained constant with increasing temperature.

The SEM micrographs of compositions sintered at $1300{ }^{\circ} \mathrm{C}$ are shown in Fig. 6. In these micrographs it is possible to evaluate primary mullite, secundary mullite, glass phase regions, and alumina and/or quartz particles dispersed in glass phase. The micrograph of composition Q (Fig. 6a) 

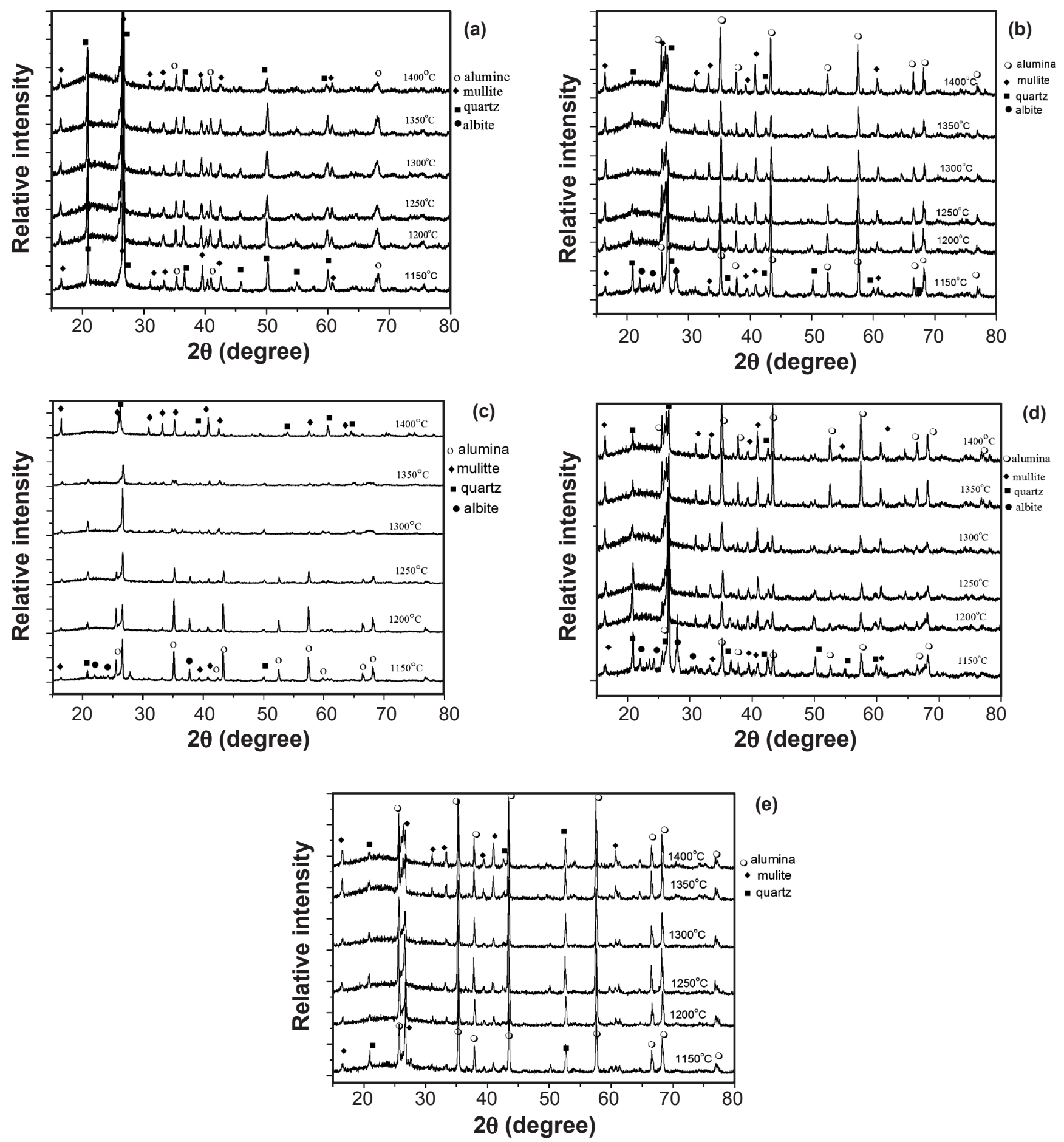

Figure 5: XRD patterns of compositions sintered at different temperatures: (a) Q (quartz), (b) B (refractory bauxite), (c) RH (reprecipitated aluminium hydroxide), (d) BH (Bayer aluminium hydroxide), and (e) A (alumina).

[Figura 5: Difratogramas de raios X de composições sinterizadas a diferentes temperaturas: (a) Q (quartzo), (b) B (bauxita refratária), (c) RH (hidróxido de alumínio reprecipitado), (d) BH (hidróxido de alumínio Bayer, e (e) A (alumina.]

shows the presence of a vitreous phase in which quartz grains about $10 \mu \mathrm{m}$ in size are dispersed. Furthermore, the presence of primary and secundary mullite can be observed. The quartz grain has rounded edges due to its dissolution in the glassy phase. Note also the cracking around the quartz particles, arising from differences in the thermal expansion coefficients of the matrix and particles of quartz [25]. The primary mullite is in the form of an aggregate of small crystals and is formed from the clay, and the secondary mullite is in the form of prismatic needles formed in the region of feldspar. The secondary mullite originates from the outer surface of the primary mullite and grows in the region of lower viscosity [17].

In composition $\mathrm{B}$, shown in Fig. $6 \mathrm{~b}$, it is possible to 

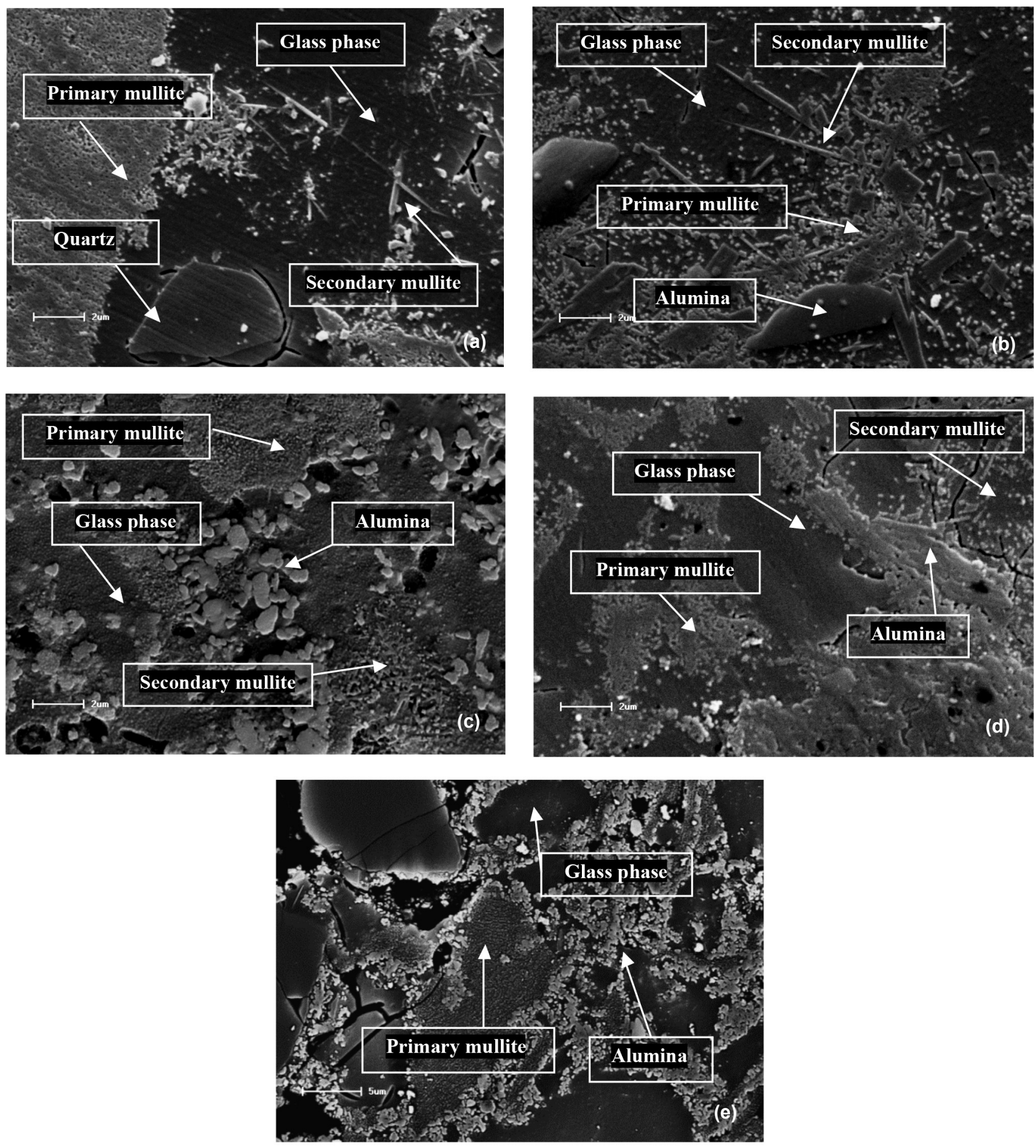

Figure 6: SEM micrographs of porcelain compositions sintered at $1300{ }^{\circ} \mathrm{C}$ : (a) Q (quartz), (b) B (refractory bauxite), (c) RH (reprecipitated aluminium hydroxide), (d) BH (Bayer aluminium hydroxide), and (e) A (alumina).

[Figura 6: Micrografias obtidas em microscópio eletrônico de varredura de composições de porcelana sinterizadas a $1300{ }^{\circ} \mathrm{C}$ : (a) $Q$ (quartzo), (b) B (bauxita refratária), (c) RH (hidróxido de alumínio reprecipitado), (d) BH (hidróxido de alumínio Bayer, e (e) A (alumina.]

observe the formation of primary and secondary mullite, an alumina grain size of approximately $10 \mu \mathrm{m}$ with irregular shape, and a glassy phase in which these phases are disposed. Composition RH (Fig. 6c) shows a microstrucutre with primary mullite, glass phase, and alumina, which is very thin, with a size of less than $1 \mu \mathrm{m}$. The presence of primary mullite phases, secondary mullite, and agglomerates of alumina can be observed in composition BH (Fig. 6d).

Fig. 7 shows a micrograph of these alumina agglomerates. This morphology comes from the agglomerates of Bayer aluminium hydroxide used as raw material. The Bayer aluminium hydroxide has not been ground separately, and its grinding occurred when the mixtures were prepared in a ball mill for $6 \mathrm{~h}$. For the agglomerates formed it can be 


\section{Alumina}

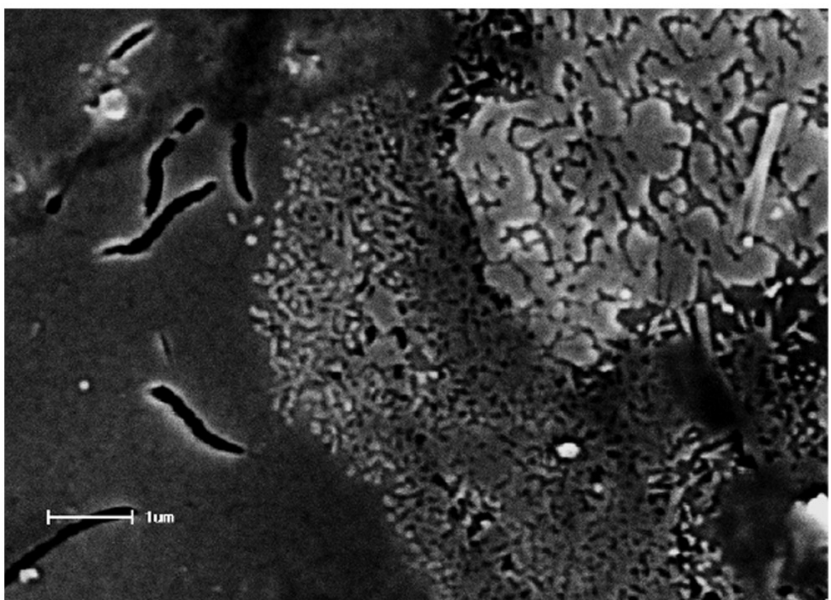

Figure 7: SEM micrograph of composition BH (Bayer aluminium hydroxide) showing agglomerated alumina.

[Figura 7: Micrografia obtida em microscópio eletrônico de varredura da composição BH (hidróxido de alumínio Bayer) mostrando aglomerados de alumina.] verified that the grinding was not totally efficient in breaking up the agglomerates and distributing the material evenly throughout the hydroxide.

The images shown in Fig. 8 confirm this statement. Figure 8a shows the morphology of the Bayer aluminium hydroxide, which is in the form of rounded agglomerates with approximate sizes of $100 \mu \mathrm{m}$. Figure $8 \mathrm{~b}$ shows the microstructure of the composition $\mathrm{BH}$ sintered at $1250{ }^{\circ} \mathrm{C}$, which shows clear regions of agglomerates of approximately $20 \mu \mathrm{m}$, while Fig. $8 \mathrm{c}$ presents a magnified image of the lighter region. To confirm that this was agglomerates of alumina, a microanalysis of this region was performed, as shown in Fig. 8d, which reveals that only aluminium and oxygen are present, indicating that these clusters are alumina. It was not possible to observe the presence of secondary mullite in microstructures of composition A (Fig. 6e). During sintering, the secondary mullite is formed from the clay and grows towards the liquid originating from the feldspar [19]. The liquid from feldspar is more fluid than the liquid

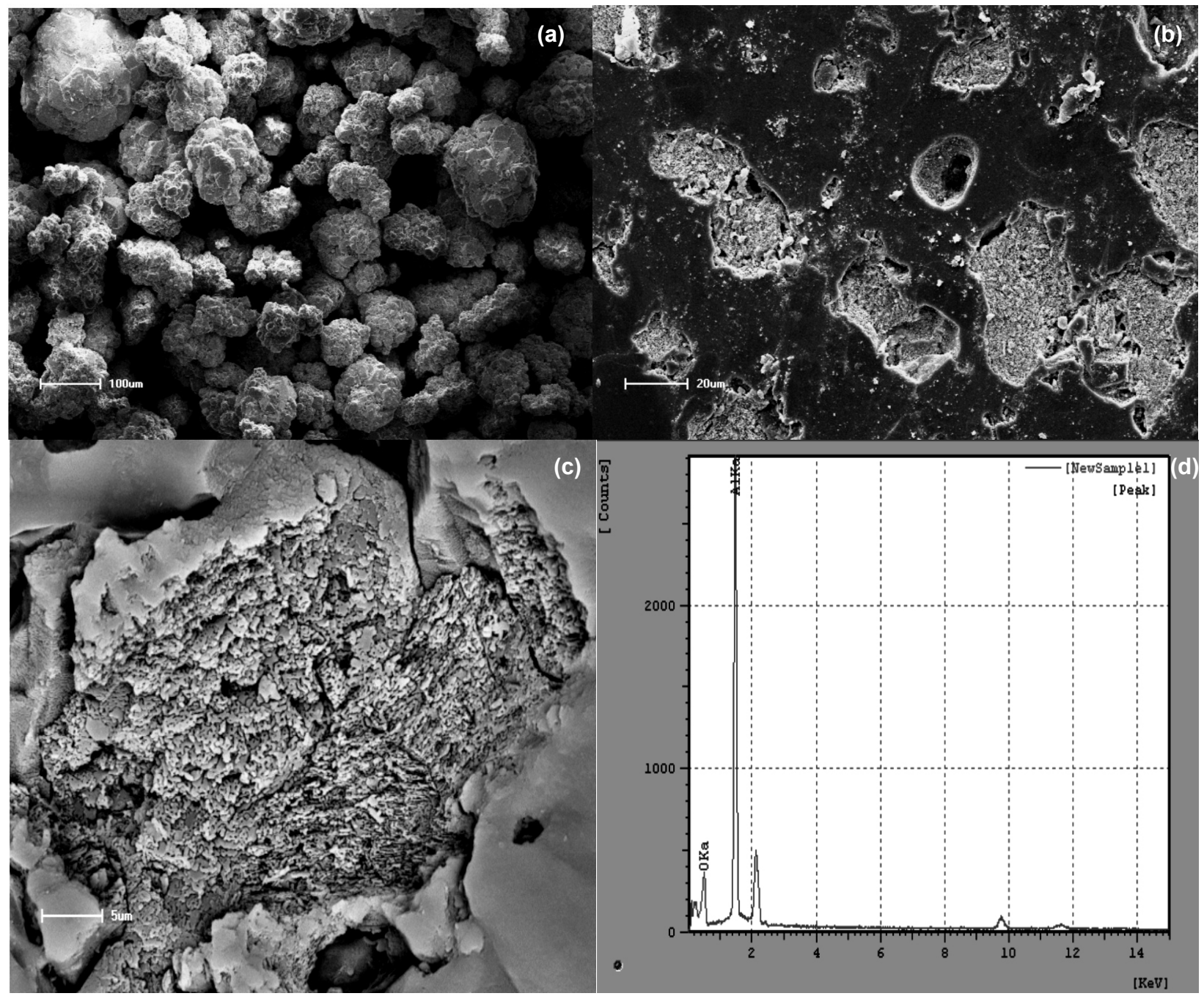

Figure 8: SEM micrographs of (a) Bayer aluminium hydroxide raw material, (b) BH (Bayer aluminium hydroxide), (c) lighter region in the microstructure, and (d) micro-analysis (EDS) of the lighter region.

[Figura 8: Micrografias obtidas em microscópio eletrônico de varredura (a) do hidróxido de alumínio Bayer, (b) da composição BH, (c) da região mais clara na microestrutura e (d) microanálise (EDS) da região mais clara. 
from the clay and hence it has a high amount of alkaline and alkaline earth ions and, consequently, the secondary mullite crystals are larger than those of the primary mullite. Thus, the fact that alumina particles have agglomerated, probably due to their small initial particle size and positioning around the primary particles of mullite during sintering, could have prevented the growth of secondary mullite. The alumina can be observed with backscattered electrons and appears as small grains of lighter clusters around the primary mullite.

Experimentally it is observed that the mechanical strength of porcelain is a result of the concomitant effect of various factors such as the amount and size of mullite, the size and shape of dispersed particles of quartz and/or alumina, the difference in the expansion coefficients of the vitreous phase and crystalline phases, and the mechanical properties characteristic of the glassy phase [23]. Fig. 9 shows the maximum values of mechanical strength versus sintering temperatures for all compositions.

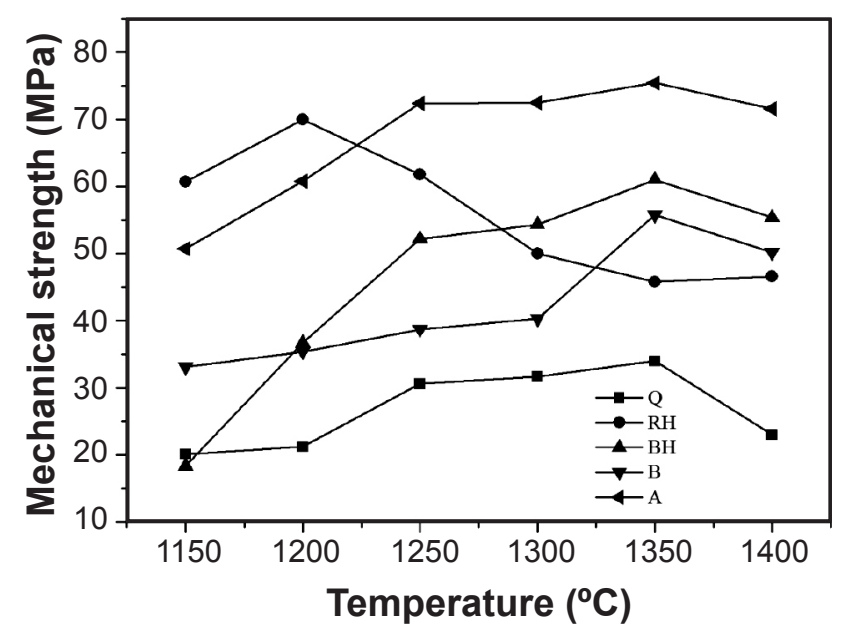

Figure 9: Mechanical strength versus sintering temperature for compositions: Q (quartz), B (refractory bauxite); RH (reprecipitated aluminium hydroxide); $\mathrm{BH}$ (Bayer aluminium hydroxide); and $\mathrm{A}$ (alumina).

[Figura 9: Resistência mecânica versus temperatura de sinterização para as composições: $Q$ (quartzo), B (bauxita refratária), $R H$ (hidróxido de alumínio reprecipitado), BH (hidróxido de alumínio Bayer), e A (alumina).]

All compositions that contain alumina have a higher mechanical strength than the base composition (100\% quartz). This indicates that the presence of alumina, regardless of the source used, causes an increase in the mechanical strength, probably through the mechanism of strengthening of particles by dispersion. The particles dispersed in the glass matrix act to stop the propagation of cracks. Furthermore, the replacement of quartz by alumina reduces the difference in thermal expansion coefficient between the glass phase and the crystal phase, thereby decreasing the possibility of cracking, and the mechanical strength of the porcelain is increased. When the different sources of alumina are compared, it is found that compositions with alumina have the highest mechanical strength compared to other compositions.

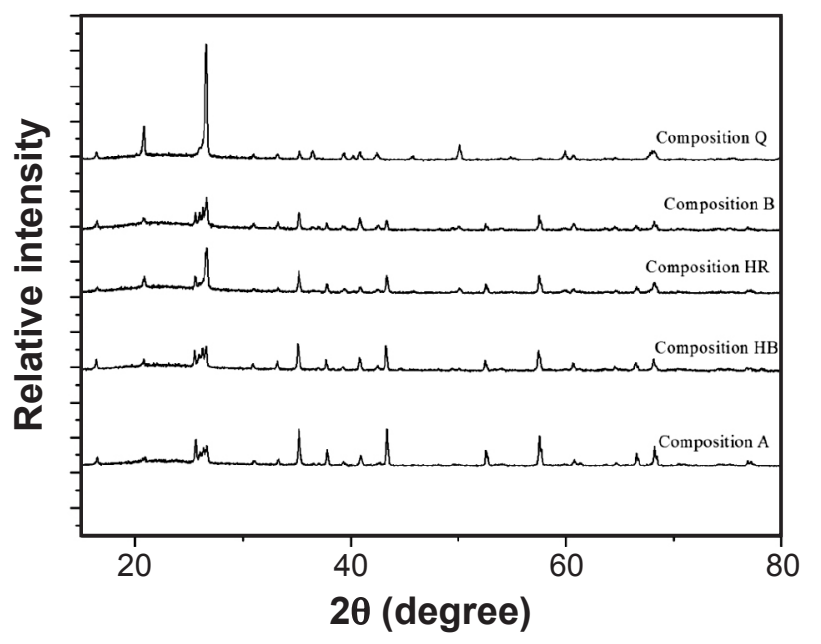

Figure 10: XRD patterns for compositions that presented higher mechanical strength for compositions: Q (quartz), B (refractory bauxite); RH (reprecipitated aluminium hydroxide); BH (Bayer aluminium hydroxide); and A (alumina).

[Figura 10: Difratogramas de raios $X$ das composições que apresentaram maiores valores de resistência mecânica: $Q$ (quartzo), $B$ (bauxita refratária), $R H$ (hidróxido de alumínio reprecipitado), $B H$ (hidróxido de alumínio Bayer), e A (alumina.]

Fig. 10 shows the XRD patterns of compositions that presented higher mechanical strength. The peaks related to mullite are practically the same for all compositions. This indicates that the hypothesis that the mullite explains the mechanical strength does not apply. The main difference between the phases is formed in the presence of particles of alumina and quartz.

The higher mechanical strength of the porcelain produced with calcined alumina can be initially assigned to the higher amount of $\alpha$-alumina, as can be seen in Table II. Another factor that has a major influence is the particle size of alumina used. It is widely discussed in the literature that the particle size of alumina has a large influence on the mechanical strength of aluminous porcelains. It has been shown that the size and shape of alumina crystals have a significant effect on the properties of porcelain and suggested that the size of the alumina particles should not exceed $3 \mu \mathrm{m}$ and the particles must be quite well dispersed in the matrix [40]. In this study, the average particle size of alumina used is about $0.9 \mu \mathrm{m}$, and a tendency to agglomerate was observed by SEM.

The alumina derived from bauxite has a larger average particle size of about $5 \mu \mathrm{m}$ as well as providing a more irregular shape, as shown in Fig. 6b. Among the aluminium hydroxides, it is noted that reprecipated aluminium hydroxide presents a higher mechanical strength than the Bayer aluminium hydroxide, which can be associated with the smaller particle size of reprecipitated hydroxide.

\section{CONCLUSIONS}

Based on the results of replacement of quartz by others sources of alumina, it can be concluded that the use of 
bauxite and aluminium hydroxide as a source is possible and viable. The substitution of these materials causes an increase in mechanical strength without increasing the sintering temperatures. The main mechanism of mechanical strength improvement observed in compositions was the dispersion of particles of alumina in the glassy phase and it was confirmed that the grain size of particles is a fundamental factor for the control of mechanical properties of aluminous porcelains

\section{REFERENCES}

[1] E. Wilhelm, Silicate Science - Silicate Structure, Academic Press, New York, USA (1964).

[2] V. E. Henkes, G. Y. Onoda, W. M. Carty, Science of Whitewares, The American Ceramic Society, Westerville, Ohio (1996).

[3] R. Biensen, G. A. Geyer, K. H. Schuller, "Investigations concerning the workability and properties of a high-alumina porcelain body", Ceram. Forum Int./Ber. DKG. 64 (1987) 376.

[4] A. M. Bishai, B. H. F. Al-Khayat, F. A. Awni, "Dielectric and physicomechanical properties of electrical porcelain bodies", Am. Ceram. Soc. Bull. 64 (1985) 598.

[5] E. P Goulart, M. Jordão, D. D. D. Souza, P. K. Kiyohara, "Correlação entre o Comportamento Mecânico e a Microestrutura de Porcelanas com Teores Crescentes de Alumina", Cerâmica 36 (1990) 32.

[6] I. A. Popova, D. B. Kreimer, "Choice of the aluminafeldspar ratio in high-strength porcelain bodies", Glass Ceram. 47 (1990) 90.

[7] Y. Kobayashi, O. Ohira, T. Satoh, E. Kato, “Compositions for strengthening porcelain bodies in alumina-feldsparkaolin system", Br. Ceram. Trans. 93 (1994) 49.

[8] G. Pena, A. G. Verduch, F. S. Del Rio, "Modification of the plastic component of high alumina porcelain by illitic clay additions", Interceram 5 (1988) 65.

[9] K. N. Maite, S. Kumar, "Effect of glass-ceramics and sillimanite sand additions on the microstructure and properties of porcelain", Ceram. Int. 18 (1992) 403.

[10] W. P. Tai, K. Kimura, K. Jinnai, "Processing of lightweight, high-strength porcelains using an alumina cement to replace feldspars and clays", J. Am. Ceram. Soc. 83 (2000) 1658.

[11] F. H. Norton, Introdução a tecnologia cerâmica, Ed. Edgard Blucher, S. Paulo, SP, Brazil (1973).

[12] S. R. Bragança, C. P. Bergmann, "Aspectos teóricos e práticos sobre a resistência mecânica em porcelanas", Cerâmica 50 (2004) 145.

[13] W. M. Carty, U. Senapati, "Porcelain: raw materials, processing, phase evolution and mechanical behavior", J. Am. Ceram. Soc. 8 (1998) 3.

[14] A. K. Ismailov, "Thermodynamic analysis of the formation of mullite from kaolinite", Glass Ceram. (1981) 363.

[15] S. Villegas-Palacio, D. R. Dinger, "PSD Effects on Firing Properties of Porcelain I" Am. Ceram. Soc. Bull. 75, 7 (1996) 71.
[16] S. Villegas-Palacio, D. R. Dinger, "PSD Effects on Firing Properties of Porcelain, II", Am. Ceram. Soc. Bull. 75, 9 (1996) 79.

[17] Y. Iqbal, W. E. Lee, "Microstructural evolution in triaxial porcelain", J. Am. Ceram. Soc. 83 (2000) 3121.

[18] A. L. Chinelatto, "Efeito de terras raras no desenvolvimento da microestrutura e nas propriedades de porcelanas aluminosas", Tese Dr. Ciência e Engenharia de Materiais, UFSCa, S. Carlos, SP, Brazil (2002) 206 p.

[19] Y. Iqbal, W. E. Lee, "Fired porcelain microstructures revisited", J. Am. Ceram. Soc. 82 (1999) 3584.

[20] L. Liebermann, W. Schulle, "Bauxite porcelain: A new high-tech product for high-voltage insulation", Am. Ceram. Soc. Bull. 81 (2002) 33.

[21] A. Bernasconi, V. Diella, A. Pagani, A. Pavese, F. Francescon, K. Young, J. Stuart, L. Tunnicliffe, "The role of firing temperature, firing time and quartz grain size on phase-formation, thermal dilatation and water absorption in sanitary-ware vitreous bodies", J. Eur. Ceram. Soc. 31 (2011) 53.

[22] A. L. Chinelatto, D. P. F. D. Souza, "Porcelanas elétricas aluminosas: Parte I - Revisão da literatura", Cerâmica 50 (2004) 62.

[23] A. L. Chinelatto, D. P. F. D. Souza, "Porcelanas elétricas aluminosas: Parte II - desenvolvimento da microestrutura e sua influência no módulo de ruptura", Cerâmica 50 (2004) 172.

[24] G. N. Maslennikova, Y. T. Platov, "The process of porcelain formation in the presence of additives (a review)", Glass Ceram. 55 (1998) 49.

[25] D. Wattanasiriwech, S. Wattanasiriwech, "Fluxing action of illite and microcline in a triaxial porcelain body", J. Eur. Ceram. Soc. 31 (2011) 1371.

[26] W. E. Lee, Y. Iqbal, "Influence of mixing on mullite formation in porcelain", J. Eur. Ceram. Soc. 21 (2001) 2583. [27] http://www.alcoa.com/brazil, accessed in March 2011.

[28] http://www.abal.org.br/aluminio/introducao.asp, accessed in Jan. 2011.

[29] C. P. Massola, "Flotação reversa da bauxita de Miraí, MG”, Diss. Mestrado, Escola Politécnica, USP, S. Paulo, SP, Brazil (2008) 85 p.

[30] M. C. M. Toledo, "Evolução geoquímica mineralógica, micromorfológia no processo de bauxitização: estudo comparativo dos depósitos de Mogi das Cruzes, Curucutu e Lavrinhas, SP, associados a diferentes tipos litológicos", Diss. Mestrado, Instituto de Geociências, Universidade de S. Paulo, SP, Brazil (1981) 106 p.

[31] C. Pascoal, V. C. Pandolfelli, "Bauxitas refratárias: Composição química, fases e propriedades - Parte I", Cerâmica 46 (2000) 76.

[32] http://www.alcoa.com/brazil/pt/custom_page/mercados_ alumina.asp, accessed in 27 April 2011.

[33] E. C. Damasceno, J. C. C. Flôres, "A bauxita e a indústria do alumínio” (Bol. Tec. BT/PMI 1077), EPUSP, S. Paulo, SP, Brazil (1998) 26 p.

[34] S. H. Souza, P. K Kiyohora, S. P. Souza, “Transformation of synthetic euhedral and fibillar crystals of boehmite into 
aluminas", Mater. Res. Bull. 31 (1996) 799.

[35] S. P. Souza, S. H. Souza, S. P. Toledo, "Standard transition aluminas electron microscopy studies", Mater. Res. 3 (2000) 104.

[36] R. Tomasi, "Estudo experimental da pirólise de cristais de cloreto de alumínio hexahidratado", Tese Dr. USP, S. Paulo, SP, Brazil (1988) $161 \mathrm{f}$.

[37] M. Rajendran, A. K. Bhattacharya, "Low temperature formation of alpha alumina powders from carboxylate precursors", Mater. Lett. 39 (1999) 188.

[38] S. R. Brangança, C. P. Bergmann, "Microestrutura e propriedades de porcelanas", Cerâmica 50 (2004) 291.

[39] M. M. Márquez, J. M. Rincon, M. Romero, "Effect of firing temperature on sintering of porcelain stoneware tiles", Ceram. Int. 34 (2008) 1867.

[40] R. G. Orlova, V. D. Beshentsev, J. K. Moro, E. P. Bogdanis, Glass Ceram. 45 (1988) 466.

(Rec. 23/05/2014, Rev. 06/08/2014, Ac. 18/08/2014) 